\title{
Research on the Current Situation and Cultivation of College Students' Traditional Culture Education
}

\author{
Hongxiang Zhao \\ School of economics and management, Shenyang University of Aeronautics and Astronautics
}

Keywords: Traditional culture; Education reform; Promotion way

\begin{abstract}
Chinese traditional culture refers to the spiritual and cultural level, is a sum of various Ideological cultural and sense of worth of the development of the Chinese history. The traditional culture education of college students has unreasonable curriculum, shortage of teachers, lack of subject consciousness of learning. In general, the traditional culture education of college students seriously weak. Specific analysis is due to the market economic conditions, traditional culture is lashed by multiculture. Oriented education background causes the students to ignore the importance of traditional culture. According to the above, in order to cultivate college students traditional culture, we should promote china traditional culture education reform, the mass media play the role of propagandizing and guiding, pay attention to the influence of family culture, and guide students to learn Chinese actively, and improve the whole society traditional culture's level.
\end{abstract}

\section{The Connotation of the Traditional Culture Education}

"In a broad sense, culture is the sum of the material wealth and spiritual wealth created in the process of human social history practice. In a narrow sense, culture refers to the ideology of the society, as well as to adapt to the system and organization." The so-called Chinese traditional culture, refers to the Chinese nation in the history of 5000 years' development process, in particular political, economic, cultural, social background, created and handed down the ancient culture, is a large culture of Mutual reference and mix together in the thousands of Chinese development. Broadly speaking, Chinese traditional culture including material culture, spiritual culture also contains; narrowly speaking, China traditional culture refers to the spiritual and cultural level, is a sum of various Ideological cultural and sense of worth of the development of the Chinese history. The Chinese traditional culture, traditional culture is narrow. Chinese traditional culture in this article is the narrow sense.is produced by the Chinese nation after the baptism of wind and rain ,precipitation, fusion. Traditional culture has developed and extened constantly along with the social change, themore representative school, is Confucianism, Taoism and Buddhism.

\section{The Current Situation of Traditional Culture Education of College Students}

The Traditional Culture Education Status of College Students in Universities is Still Not Reasonable.

At first, courses related to colleges and universities of traditional culture is unbalanced. Some colleges and universities set traditional culture education courses, but are limited to liberal arts universities and comprehensive universities, science college is less emphasis on the basic, even there is no such courses; Secondly, students traditional culture education is not clearly. In the fuzzy process of traditional culture education of college students, the education content selection mainly depends on the teachers' classroom teaching, it can be said that is the traditional culture content students receive. When in the process of College Students' education of traditional culture, the core content should be condensed out of the traditional culture, it is a important task of education workers. Finally, the lack of traditional culture education' teaching material. College students' education of traditional culture mainly reflected in the content of textbooks, and now in college students' education of traditional culture doesn't have national unity, and authoritative traditional culture textbooks. How to choose the teaching materials, and where do teaching materials come 
from has become a big problem.

\section{There is a Serious Shortage of Traditional Culture Education Faculty}

First, the number of university traditional culture teachers are insufficient. On the one hand, the number of scholars who are devoted to high efficient China traditional culture research is less. In the major colleges and universities or the academic circles, the traditional culture attainments are so familiar, and the range of these scholars contact students is not large. On the other hand, the traditional culture has a long history, in order to grasp accurate, comprehensively grasp, not in-depth study, not long-term effort is not up to the effect, and in the short term can not be reached, all in Colleges and universities who study traditional culture thoroughly, the number of teachers with higher levels is not much. The teaching method of traditional culture education is single. In the classroom, they ignore the students' subjectivity and autonomy role. We advocate diverse teaching methods, boycott a single boring teaching mode, but it does not mean to abandon the classroom teaching mode.

\section{College Students' Subject Consciousness is Not Strong}

College students' interest of learning is not high. The western culture occupies a large position in Contemporary College Students' mind, quite a part of students lack of interest for Chinese traditional culture, and tend to foreign film works, foreign festivals, foreign books, the traditional cultural identity of contemporary college students needs to be improved. The contemporary college students 'thoughts are active, many of the traditional culture knowledge, the value cognition of traditional culture is also inadequate, in the complicated cultural environment, it is difficult to make accurate judgments for all kinds of culture uneven in quality, cause some students to China traditional cultural identity problem, the blind worship of foreign culture, the national self-confidence by serious damage.

\section{The Atmosphere of the Campus Traditional Culture is Not Dense.}

School spirit is the atmosphere that the school presents. If a university has a great shcool spirit, contains a strong traditional culture, it is conducive to the spread of traditional culture, to cultivate students' sentiment, cultivate exalted quality, firm lofty ideal, to establish a correct outlook on life and values; conversely, bad school spirit would encourage bad style, has an adverse impact on the development of the traditional culture education of college students. At the same time, a good style of study can help the students form good learning attitude and learning habits, help students to better accept the traditional culture, promote the traditional culture education of college students smoothly; and the bad style of study will reduce the enthusiasm of students learning, so that make students sink, hinder the traditional culture education of college students. Most of the traditional culture education activities only think highly of form not content, the activities did not realize the aim of traditional culture education.

\section{Analysis of the Reasons for the Lack of Traditional Culture of College Students.}

From The Market Economy and Imbalance. Since the reform and opening up, with the shift of the working focus of the party and state, people's economic consciousness awaken, values are driven by economic interests, appeared personal interests as the center of individualism and other bad values.

This individualism has brought the imbalance of values, to some extent, it brings to people's ideas and values' confusion and moral anomie. In the background of the development of socialist market economy, the traditional to suppress people's interest and desire to improve the moral values is biased. But with the further development of market economy, people begin to pay attention to the effectiveness and benefits, with money and material benefits to the measure all things' value. The value of utilitarianism, pragmatism, mammonism and other bad ideas rise, that seriously damage social morality

The Impact of Multicultural Education on Traditional Culture Education. First of all, foreign culture lash traditional culture education. With the open doors of reform and opening up, many Western cultural thoughts come in a throng, whether it is the field of Sociology of pragmatism, philosophy of existentialism, economics of consumerism, also is in the field of psychology of 
humanism, all make Contemporary College Students' values and thinking change a lot. Secondly, the network culture challenges the traditional culture education. In recent years, with the popularity of the Internet, the network as the carrier of network culture came into being. Its openness, variability, timeliness and other unique characteristics, network culture permeates all aspects of social life, and has an important impact on learning, people's life, and working. Finally, the popular culture diminishes traditional culture education. Desalination represented by popular culture's way of thinking, behavior, values of contemporary have caused college student's resonance, have impact on Contemporary College Students' life and learning.

Examination Oriented Education Neglects the Cultivation of Humanistic Quality. First of all, colleges and universities pay a attention to knowledge and skill education, despise to cultivate the humanistic quality. In order to improve college students' ability to adapt to society and employment rate, higher education gradually to pay a attention to knowledge education and despise humanities literacy education, traditional culture education of college students has been adversely affected. Secondly, learning traditional culture has a slow efficiency, some universities pay little attention to it. In today's society ,pace of life is increasingly fast, more and more people to pursuit efficiency, the learning of traditional culture is never immediate, learning traditional culture can't be speeded up in a short period of time, but also did not like the professional learning that can bring direct economic benefits and social benefit.

Parents Moral Cultivation and Cultural Quality is Not High. The influence of family culture comes from cultural conditions which are supplied by parents for the children and their own cultural attainments. Parents' moral and cultural quality will influence children's literacy and virtue. Contemporary college students' parents were limited by age education quality and low quantity, resulting in the moral and cultural quality is generally low.

Contemporary College Students Lack of Awareness of the Necessity of Traditional Culture Education. First of all, the lack of traditional cultural beliefs. Many people pay attention to Material things, neglect spiritual enjoyment. Contemporary college students grew up in comfortable environment do not understand the traditional virtues of thrift, hard work and other meaning, formed the thoughts of thinking highly of material things and looking down upon the spiritual enjoyment, which have a bed influence on contemporary university students' traditional culture education. Finally, the negative influence of pragmatism, practical tendency of contemporary university students' value concept is serious. With the reform and opening up, open doors, pragmatism went into China, pragmatism thought as the guiding ideology of some college students to measure the value of things, its purpose is whether starting points is "useful" and whether it can bring economic benefits.

\section{Ways of Cultivating College Students' Traditional Culture}

Promote the China Traditional Culture Education's Reform. Firstly, dig Chinese traditional culture education content. In the selection of traditional culture's content, to ensure the taste of traditional culture education, age and life style. and to improve the methods of China traditional culture education. And universities should focus on the permeability of university curriculum integration, and attach great importance to the combination of Science education courses and humanistic education curriculum, especially for science and engineering students, pay attention to the cultivation of scientific literacy, similarly, cultivate humanistic quality education especially China traditional culture education, improving the qualities of traditional culture. Secondly, universities should improve the teaching level of university teachers. The quality of teachers' chinese traditional culture will directly affect the quality and level of traditional culture education of college students. Each university teachers should establish the concept of lifelong learning, constantly enrich their cultural knowledge, constantly absorb nutrients from learning, enhance their own culture engaged in the education of traditional culture heritage. Chinese teachers should have profound knowledge and elegant aesthetic taste. It requires teachers to constantly reflect on their own shortcomings, should learn to be educated, constantly learning new knowledge, deepen the breadth and depth of their knowledge, every teacher should become knowledgeable scholar. 
Play the Role of Propaganda and Guidance of Mass Media. To use the mass media's Intuitive ,legibility, reciprocity and popularity to expand the traditional voice and influence. On the other hand, to improve the quality and level of mass media content, they can convy some jerky, boring traditional culture with vivid, profound interpretation, to enhance the traditional culture's attraction and infectivity. It can make students be willing to learn, cause the resonance, give full play to the role of culture to inspire people, motivate people, improve students' understanding of traditional culture, on the basis of these, students can understand traditional culture more easily. Finally, to focus on the positive guidance of the mass media, to strengthen the management of the Internet, to reduce the negative impact of mass media. According to the law, to increase management network efforts to improve the leadership system of Internet governance, the relevant government departments to do the supervision work on the Internet and other media, to ensure the correct orientation of public opinion of media, make the excellent traditional culture essence spread to the public.

To Guide College Students' Active Learning of Chinese Traditional Culture. To cultivate and arouse students' learning Chinese traditional culture's interest, through learning and comprehension, which are easy to stimulate interest in traditional culture, to stimulate students to deeply study the traditional culture, so as to realize the improvement of College Students' Chinese qualities of traditional culture in the process of learning and acceptance, to understand and transform the world with the scientific method of thinking. On the other hand, students should use their own cultural quality's advantage, consciously take the traditional culture inheritance and innovation mission, inherit and carry forward the essence of traditional culture, and constantly promote the development of innovative and creative transformation of traditional culture. College students play the main role, to improve the students' Moral Cultivation and Practice ability. Colledge students should take part in the cultural practice and work practice. Through practical activities, make the inner quality and outside morality transfer to cultural practice, through the practice of cultural activities to enhance the consolidation of cultural literacy.

Attaching Importance to Family Culture. To improve the moral and cultural qualities of the parents. Parents personal moral cultivation and cultural quality will exert a subtle influence on children, parents cultivate noble personality and higher literacy play a social subject role for children literacy and moral cultivation which cannot be substituted. Parents should change education idea, update ideas, parents should take children's education task, not entirely take it to the school and the society. Parents should be fully aware of the emotional education and life on the significance and value of children's education, strengthen the sense of responsibility and initiative. In the premise of its own initiative to mobilize students, cultivating students' China traditional culture, form the quality of society, school, family "three-in-one" education.

\section{References}

[1] Xu Qi, Research on the innovation of teaching management system in Colleges and universities for training applied talents [J], Statistics and Management. (2015) 12:157-158.

[2] Li Juan, Innovation of teaching management system in Colleges and Universities Based on innovative talents training [J], Management. (2014) 35:322.

[3] Yan Dong, Li Yanlin, Innovation of teaching management system in Colleges and Universities under the concept of innovative talents training $[\mathrm{J}]$, China off campus education. (2014) S3:221.

[4] Lin Yanfang, Innovation of teaching management system in Colleges and Universities Based on innovative talents training [J], Asia Pacific Education. (2015) 21:243.

[5] Sun Donghui, Innovative talent training concept of college teaching management system innovation [J], China Adult Education. (2015) 14:41-42.

[6] Zhou Lianfang, College Teaching Management Research Based on innovative talents training 
[J], Journal of Kaifeng Institute of Education. (2010) 04:51-53.

[7] Jin Lu, Reform of college teaching management reform based on the cultivation of innovative talents [J], Higher Education Development and Evaluation. (2008) 06:34-38+121-122.

[8] Liang Xiushan, on the teaching management innovation of Applied Talents Cultivation [J], Contemporary Education Forum (Principal Education Research), (2008) 08:32-34. 